\title{
THE EFFORT TO INCREASE STUDENT'S LEARNING OUTCOMES USING COOPERATIVE LEARNING EXAMPLE NON EXAMPLE
}

\author{
Mardanis ${ }^{1}$, Agus Sudargono ${ }^{2}$, MS. Khabibur $\mathrm{R}^{3}$ \\ Geography Education Study Program, Veteran Bangun Nusantara University, Sukoharjo \\ Email: mardanisd14@gmail.com
}

\begin{abstract}
The purpose of this study was to determine the effect of the example non example method about the dynamics of the hydrosphere and its impact on the life of social science learning. The sample of this study is class X IPS 4 in STATE 3 HIGH SCHOOL, Sukoharjo. This is Classroom Action Research study that used Example Non Example method using images. The result showed that the learning outcomes of students was increased from 83,11\% to 86,33\% at the first Cycle and continued to increase to $91,67 \%$ at the second cycle.
\end{abstract}

Keywords: Learning Outcomes, Example Non Example

\section{A. INTRODUCTION}

In the learning process, a teacher ideally should use interesting method or media to make students interested to follow the lesson, particularly in Geography materials. The teacher's style in implementing learning activity in an aspect can influence the success of a competency accomplishment of a lesson. Currently, the trend is still centered on teacher who lectures and tells stories while the students are less actively involved in the learning process. Moreover, media is rarely used on that process that makes learning is merely aborting obligations.

Senior High School 3 Sukoharjo is becoming one of favorite schools in Sukoharjo that is faciliticated with adequate facilities, however it does not guarantee that students pay attention to their teacher during the learning process. It can happen because the teacher is not interesting or the material delievered is difficult to understand. It is also caused by the methode that teacher used still mostly lecturing that makes students are less active when the learning process takes place.

A method that can be used to increase student activity is cooperative learning. According to Salvin (1985) cooperative learning is a learning model where students learn and work in small groups collaboratively with members of 4-6 people with heterogeneous group structures (Isjoni, M. 2013: 14). This group is expected to improve students' learning achievement, as well as to improve the ability of social relationships, foster an attitude of accepting self-deprivation and others, and can increase self-esteem (Suyadi. 2015: 62). 
Therefore, this study is conducted to find out whether the learning method of Example Non Example Cooperative Learning can affect the learning outcomes of Geography students in Class X Social Science of Senior High School 3 Sukoharjo.

\section{B. METHOD}

This research is Classroom Action Research (CAR) that is oriented to improve the learning quality. The steps of this method in this research are :

1. Selecting a number of subjects from a population.

2. Grouping a number of subjects into two groups, namely the experimental group known as variable $\mathrm{X}$, and the control group subjected to the behavior of $\mathrm{Y}$.

3. Measuring the average learning outcomes before the subject is given treatment.

4. Giving treatment $X$ to the experimental group, whereas the control group applied treatment Y.

5. Providing post-test $\mathrm{T} 2$ in the experimental group to measure the average learning achievement that has been achieved after the $\mathrm{X}$ treatment.

6. Giving posttest to the control group.

7. Determining the difference between $\mathrm{T} 1$ and $\mathrm{T} 2$ in the experimental control group to measure the average pretest-posttest $(\mathrm{Z} 1)$ difference.

8. Determining the difference between $\mathrm{T} 1$ and $\mathrm{T} 2$ in the control group to measure the average pretest-posttest (Z2) difference.

9. Comparing $\mathrm{Z} 1$ and $\mathrm{Z} 2$ to determine differences arising if there are.

10. Implementing statistical tests to determine whether the difference is significant.

\section{RESULT}

\section{Description of the initial conditions (Pre-Cycle)}

In the initial conditions before the research was carried out, the learning of Social Sciences (IPS) -Geography in class X IPS 4 of the 2018/2019 academic year still used the conventional method of lecturing and reading. Learning Geography Social Sciences in Class X Social Science Senior High School 3 Sukoharjo is still teacher-centered in which the teacher becomes the center of learning by actively delivering subject materials, while students only passively listen. This method makes students difficult to understand the materials that results low grade of students' learning outcomes. Based on the observation, the initial condition of students' learning outcomes at Geography material especially at competency of Hydrosphere Dynamics and Its Impact on ife at the observed class is describing below : 
Table 1. The Students' Initial Learning Outcomes

\begin{tabular}{|l|l|l|}
\hline No & Description & Result \\
\hline 1. & Highest Score & 83 \\
2. & Lowest Score & 66 \\
3. & Average & 74, \\
4. & Completion & 30 students $(85,71 \%)$ \\
\hline
\end{tabular}

Based on the preliminary condition, it finds out that the average value of observed class is 74 and $85,71 \%$ of them have achieved the minimum value set in Geography lesson. The highest grade is 83 while the lowest grade is 66 .

\section{Description of Cycle Action I}

The first cycle was carried out at the fourth week of April 2019 by applying Example Non Example learning on competency of Hydrosphere Dynamics and Its Impact on Life. The first cycle is continued with the post question.

a. Planning

Before implementing the first action cycle, the first step is to prepare a Learning Implementation Plan (RPP) and prepare a discussion material and post test question. Based on RPP, the time allocation of the learning process is 2 x 45 minutes.

b. Implementation

1) Meeting 1

It is held in three main activities which are initial, core, and closing activity based on the prepared implementation plan. The opening is about 5 minutes in which teacher greets the students and leads to pray together before the class is started. Then, teacher absent students and do aperception by reviewing previous materials to explore the initial knowledge of students. Next, the teacher gives students motivation about the benefit of learning the material of Hydrosphere Dynamics and Its Impact on Life followed by conveying the learning objectives material coverage.

The carried activity is carried out in 70 minutes including exploration, elaboration, and confirmation. At the exploratory stage, the teacher explains the steps of cooperative learning with Example Non Example Model and encourage students to be active at discussion. After that, teacher gives material about Hydrosphere Dynamics and Its 
Impact on Life. At the elaboration stage, teacher asks students to form groups comprising 6 students for each group to do discussion and present the result of their discussion. At the confirmation stage, teacher asks questions related to materials that are still unknown to children followed by the correction from teacher if there is misunderstanding to provide reinforcement and conclusion.

The closing activity is caried out for 20 minutes where teacher gives post-test followed by informing the next material and giving the assignments to students and finally teacher closes the class.

c. Observation

The observation result during the first cycle showed that teacher and students are able to implement the Example Non Example method properly. The teacher is able to guide the students while the students are able to follow the instruction. Some students can do discussion group properly by expressing their opinions while others are still less active by just staying quite during the discussion and some students seem unfocused by lacking their concentration. Another problem that occurs during the first cycle is the LCD that cannot be used due to blackout. The learning outcomes of students after experiencing the first cycle is served at table below.

Table 2. The learning outcomes of students at Cycle I

\begin{tabular}{|l|l|l|}
\hline No & Description & Result \\
\hline 1. & Highest Score & 90 \\
2. & Lowest Score & 30 \\
3. & Average & 74 \\
4. & Completion & 31 students $(96,87 \%)$ \\
\hline
\end{tabular}

At cycle I teacher has applied Example Non Example Model in observed class that results the average grade 74 which has reached the minimum standard value of Geography lesson. The highest score is 90 while the lowest grade is 30. Also, the completion level over students is $96,87 \%$. Therefore, it can be said that the average grade of students is increased from the initial condition. On the other hand, the lowest grade is extremely decreased from 60 to 30 because the students are less concentrate when performing the test in cycle I. 


\section{d. Reflection}

Reflection is needed to know the result of cycle I. The empirical data of students' learning outcomes at cycle I compared to initial conditian is served in Table 3.

Table 3. The increase of students' learning outcomes at cycle I

\begin{tabular}{|l|l|l|}
\hline Items & Initial Condition & Cycle I \\
\hline Action & $\begin{array}{l}\text { Apply lecturing and reading } \\
\text { Geography Material }\end{array}$ & $\begin{array}{l}\text { Apply Example Non } \\
\text { Example Model in } \\
\text { Geography Learning }\end{array}$ \\
\hline Highest Score & 83 & 90 \\
Lowes Score & 60 & 30 \\
Average & 74 & 74 \\
Completion & 30 students $(85,71 \%)$ & 31 students $(96,87 \%)$ \\
\hline
\end{tabular}

Based on above data, the initial condition of teacher is still using lecturing and reading method in the class. The average score using this method is 74 which has exceeded the minimum standard value of Geography lesson. The highest score is 83 while the lowest score is 60 and the completion level is $85,71 \%$.

At cycle I, teacher has applied the Example Non Example Model. With this method, the average score is 74 that has exceeded the minimum standard og Geography lesson. The highest score is 90 while the lowest score is 30 , and the completion level is $96,87 \%$.

In general, the learning outcomes of students is increased that can be seen from the highest score of initial condition 83 to 90 at cycle I and the completion level is increased from $85,71 \%$ to $96,87 \%$. However, the average score remains and the lowest score is decreased from 60 to 30 .

This decrease is caused by the less concentration of students while doing the test at cycle I. Although the result of cycle I has showed an increase and has exceeded the minimum standard value, but it still has not reached the $80 \%$ completion level. Consequently, there is a need to continue to cycle II by keep using Example Non Example model with some improvements. 


\section{Description of Cycle Action II}

This action is conducted at mid May 2019 with one meeting of the learning process using Example non Example that afterwards is followed by written test.

\section{a. Planning}

Before the implementation of cycle action II, there is an improvement on the learning implementation planning (RPP) based on the problems from previous action. Researcher also prepares discussion and pos test questions for cycle II. The time allocation for cycle II is $2 \mathrm{x}$ 45 minutes with the material of Hydrosphere Dynamics and Its Affect on Life.

b. Implementation

The implementation of cycle II is almost the same like cycle II. However, at the step where teacher creates student groups, the leader of each group will be called by teacher to get explanation about the material of land and sea water by using pictures as learning media. At the confirmation stage, teacher and students will involve at the question and answer session to avoid misunderstanding among students about the materials taught.

The final step of cycle II is carried out at 30 minutes. At this closing stage, students are asked to answer questions about the material of Hydrosphere Dynamics and Its Affect on Life as the post test. Afterwards, teacher will guide students to make reflection about the learning process and finally the class will be closed by praying together.

c. Observation

The observation result showed that both teacher and students can perform Example and non Example model properly. The learning process is very dynamic and all students to get actively involved in discussion. All learners follow the instruction from teacher and they can convey their ideas during discussion. After cycle II is implemented, the result of students' learning outcomes is describing below :

Table 5. The learning outcomes of students at cycle II

\begin{tabular}{|l|l|l|}
\hline No & Deskripsi & Hasil \\
\hline 1. & Nilai tertinggi & 96 \\
2. & Nilai terendah & 80 \\
3. & Nilai rata-rata & 80 \\
4. & Ketuntasan & 24 orang $(100 \%)$ \\
\hline
\end{tabular}


Based on above data, it shows that the average score of students is 80 that has exceeded the minimum standard value of Geography lesson. The highest score is 96 while the lowest score is 80 and the completion level is $100 \%$. Therefore, it can be concluded that the learning outcomes has increased generally.

\section{d. Reflection}

Table 6 peforms the comparison of students' learning outcomes between cycle I and cycle II as the reflection :

Table 6. The Comparison of students' learning outcomes between cycle I and cycle II

\begin{tabular}{|l|l|l|}
\hline Items & Cycle I & Cycle II \\
\hline Action & $\begin{array}{l}\text { Applying Example non Example at } \\
\text { Geography Lesson }\end{array}$ & $\begin{array}{l}\text { Applying Example non Example } \\
\text { at Geography Lesson }\end{array}$ \\
\hline Highest Score & 90 & 99 \\
Lowest Score & 30 & 80 \\
Average & 74 & 80 \\
Completion & 31 students $(96,87 \%)$ & 24 students $(100 \%)$ \\
\hline
\end{tabular}

From that empirical data, it can be seen that there is an increase from 90 to 96 as the highest score from cycle I to cycle II, from 30 to 80 for the lowest score, from 74 to 80 for the average score, and $96,87 \%$ to $100 \%$ for the completion level. Therefore, it can be said that cycle II succeeds to fulfill all performance indicator criteria of this study in which the average score is up to standard minimum value of Geography and the completion level is reached $80 \%$. So, researcher decides to finish this classroom action research.

\section{Discussion}

After Example and Non Example model has been implemented, the data about students' learning outcomes in all phases is presented below : 
Table 7. The students' learning outcomes in all phases

\begin{tabular}{|l|l|l|l|}
\hline Items & Initial Conditiion & Cycle I & Cycle II \\
\hline Action & $\begin{array}{l}\text { Applying lecturing } \\
\text { and reading in } \\
\text { Geography lesson }\end{array}$ & $\begin{array}{l}\text { Applying Example } \\
\text { non Example model } \\
\text { in Geography lesson }\end{array}$ & $\begin{array}{l}\text { Applying Example non } \\
\text { Example model in } \\
\text { Geography lesson }\end{array}$ \\
\hline Highest Score & 83 & 90 & 96 \\
Lowest Score & 60 & 30 & 80 \\
Average & 74 & 74 & 80 \\
Completion & 30 orang $(85,71 \%)$ & 31 orang $(96,87 \%)$ & 24 orang $(100 \%)$ \\
\hline
\end{tabular}

From Table X, it shows that cooperative learning using Example Non Example Model can increase the learning outcomes of Geography students at class X Social Science 4 Senior High School 3 Sukoharjo. It can be seen from the average score that increase from 74 at initial condition and remains till cycle I to 80 at cycle II. Also, the completion level is rising from $85,71 \%$ at the initial condition to $96,87 \%$ at cycle I to $100 \%$ at cycle II.

\section{E. CONCLUSION}

The conclusion of this research is the model of cooperative learning using Example Non Example can increase the learning outcomes of Geography students at class $\mathrm{X}$ Social Science 4 Senior High School 3 Sukoharjo in Academic Year 2018/2019. This increase is showed at the average score from the initial condition $83,11 \%$ to $86,33 \%$ at cycle I to $91,67 \%$ at cycle II.

\section{F. REFERENCE}

Anas Salahudin. 2015. Penelitian Tindakan Kelas. Bandung: Pustaka Setia.

Dimyati dan Mudjiono. 2009. Belajar dan Pembelajaran. Jakarta: PT Rineka Cipta.

Hasan Basri. 2015. Paradigma Baru Sistem Pembelajaran. Bandung: Pustaka Setia.

Isjoni. 2013. Pembelajaran Koorperatif. Yogyakarta: Pustaka Belajar.

Miftahul Huda. 2014. Model-Model Pengajaran dan Pembelajaran. Yogyakarta:Pustaka Belajar.

Mulyasa. 2016. Praktik Penelitian Tindakan Kelas. Bandung: PT Remaja Rosdakarya.

Oemar Hamalik. 2015. Proses Belajar Mengajar. Jakarta: PT Bumi Aksara.

S. Eka Putro Widoyoko. 2016. Evaluasi Program Pembelajaran.Yogyakarta: Pustaka Pelajar.

Sumarmi. 2012. Model-Model Pembelajaran Geografi. Malang. Aditiya Media Publishing.

Suryono dan Hariyanto. 2016. Belajar dan Pembelajaran. Bandung: PT Remaja Rosdakarya. 
Sugiyono. 2014. Metode Penelitian Pendidikan (Pendekatan Kuantitatif， Kualitatif, dan R\&D). Bandung: Afabeta, CV.

Sugiyono. 2017. Metode Penelitian Kualitatif. Bandung: Alfabeta, CV.

Suyadi. 2015. Strategi Pembelajaran Pendidikan Karakter. Bandung:PT Remaja Rosdakarya. Zainal. 2014. Penelitian Tindakan. Bandung: PT Remaja Rosdakarya.

http://digilib.unila.ac.id/22788/2/SKRIPSI\%20TANPA\%20BAB\%20PEMBAHASAN.pdf diakses:

29 Januari 2019.

http://journal.upgris.ac.id/index.php/malihpeddas/article/download/1765/1424 diakses 14 Mei 2019. http://jurnal.fkip.uns.ac.id/index.php/sosant/article/view/5716 diakses 14 Mei 2019 http://jurnal.unka.ac.id/index.php/fkip/article/download/150/pdf diakses 14 Mei 2019 http://jurnal.untan.ac.id/index.php/jpdpb/article/view/1881_ diakses 14 Mei 2019 http://sekolah.data.kemdikbud.go.id/index.php/chome/profil/f00028aa-12c7-4496-8714$518976 \mathrm{~b} 69712$ http://www.jurnal.unsyiah.ac.id/PEAR/article/download/7541/6208 diakses: 14 Mei 2019. http://www.jurnal.unsyiah.ac.id/PEAR/article/download/7541/6208 diakses: 26 Mei 2019. https://eprints.uny.ac.id/30695/1/Tri\%20Murhanjati\%20Sholihah\%201151ccccc. pdf diakses: 28 Januari 2019. 